
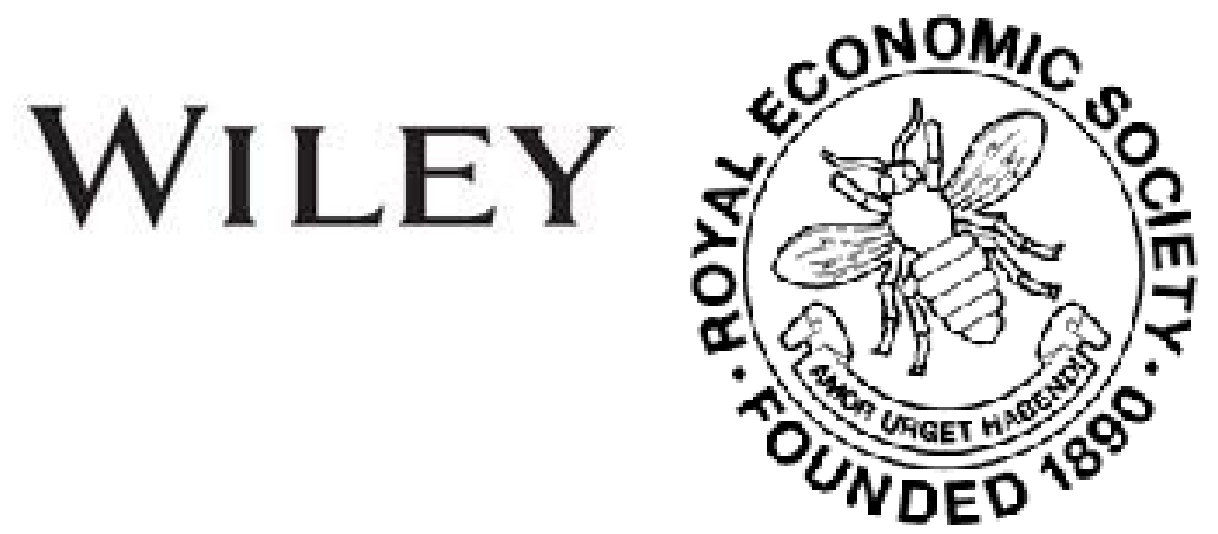

Report of an Enquiry by the Board of Trade into Working-Class Rents, Housing, and Retail Prices, together with the Rates of Wages in certain Occupations in the Principal Industrial Towns of France Author(s): A. D. Webb

Source: The Economic Journal, Vol. 19, No. 74 (Jun., 1909), pp. 323-328

Published by: Wiley on behalf of the Royal Economic Society

Stable URL: http://www.jstor.org/stable/2221465

Accessed: 24-06-2016 21:01 UTC

\footnotetext{
Your use of the JSTOR archive indicates your acceptance of the Terms \& Conditions of Use, available at http://about.jstor.org/terms
}

JSTOR is a not-for-profit service that helps scholars, researchers, and students discover, use, and build upon a wide range of content in a trusted digital archive. We use information technology and tools to increase productivity and facilitate new forms of scholarship. For more information about JSTOR, please contact support@jstor.org.

Wiley, Royal Economic Society are collaborating with JSTOR to digitize, preserve and extend access to The Economic Journal 
an annual charge on the national exchequer. Two schemes are presented in detail, the one involving the yearly afforestation of 150,000 acres, with a total of $9,000,000$ acres ; the other, 75,000 acres annually, with a total of $6,000,000$ acres. The annual capital sum involved in the two cases is estimated at two millions and one million sterling respectively, the net annual deficit being $£ 90,000$ and $£ 45,000$. While some revenue may be expected from the forests after the twentieth year, it is not till the sixtyfirst that they become self-supporting, though they would be nearly so after the fortieth year. At the end of eighty years the net revenue is estimated at more than twenty-one millions for the larger scheme, representing 33 per cent. on the accumulated charges. The Report is signed by all the Commissioners, though Mr. Stanley Wilson adds reservations in regard to the quality of "unemployed" labour, and risks from fire, pests, \&c.

WILLIAM SOMERVILLE

Report of an Enquiry by the Board of Trade into Working-Class Rents, Housing, and Retail Prices, together with the Rates of Wages in certain occupations in the Principal Industrial Towns of France. [Cd. 4512.] 1909. Price 4s. $1 d$.

THIs report is the third of a series embodying the results of a detailed and extensive investigation by the Board of Trade into the cost of living of the working classes in industrial towns. The first report dealt with the cost of living in the United Kingdom (reviewed in this Journal in June, 1908), and the second with the cost of living in Germany (reviewed in this JoURNAL in September, 1908). The present report relates to France, and covers mainly, like its predecessors, housing conditions and rents, food consumption and food prices, and wages and hours of labour in certain selected occupations. Thirty widely distributed towns were visited by the investigators, ranging in size from the capital, with its 2,760,000 inhabitants, to Fougères with 24,000. Besides the introduction and general report, summarising the results of the inquiry and comparing them with the results found in the case of England and Wales and Germany, there is a separate report on each town, in which much useful and interesting information is given, not only on housing, food, and wages, but also on industrial organisation, workmen's societies, co-operative societies, local government and taxation, vital statistics, and other matters. 
The scope and methods of the investigation have been, as far as practicable, identical in all three countries, while for purposes of comparison index numbers have been used.

As regards rent in France, quotations for about 60,000 working-class tenements were obtained from tenants, municipal authorities, and house owners. These rents, unlike the English, do not include directly any elements of local taxation, not even, as a rule, any charge for water. The Frenchman follows largely the German practice, and pays his local charges by means of additions to the State taxes, and by the octroi. It is accordingly stated to be practically impossible to ascertain the amount of local taxation paid by the French working-class family. Paris, like Berlin, but unlike London, does not contain within itself numerous examples of all the types of working-class dwellings found to prevail in the rest of the country. The comparison of rents is therefore made on the basis of the "mean predominant rents" for the several classes of tenements in all the towns taken together. The ratio found for Paris is then expressed as 100, and the ratios for the remaining towns adjusted accordingly.

Quotations of retail prices for food, coal, and paraffin oil were obtained from shopkeepers and co-operative societies, and were those usually paid by the working classes in October, 1905. Since coal is practically not used by these classes in many of the towns, wood taking its place, the index numbers are based on food prices alone. These were weighted by numbers proportional to the quantities of food consumed by a family in a normal week, as deduced from 5,605 budgets of such families. These budgets revealed that the family income spent on food (excluding wine and beer) varied from five to six times that expended on rent, whence, in constructing index numbers representing rent and food prices combined, the latter are given a weight of five, and the former a weight of one. The proportion of family income spent on rent by the working classes in the United Kingdom and Germany, as recorded in the family budgets collected in those countries, was unfortunately not published. Another interesting fact brought out by the French budgets was the relatively large contribution made by the wife and children to the total family income. In those families whose income reached less than $40 \mathrm{~s}$. a week, the wife's share amounted, on the average, to from 8.6 per cent. to 14.5 per cent. of the total, while the children's share varied from 3 to 10 per cent. These facts are mainly explicable by the comparative absence of very young children in the family. The German budgets showed very much smaller 
shares of the total income to be furnished by the wife and children. Similar information is not available for the United Kingdom.

The level of wages in the French towns is indicated by index numbers based on the "predominant time rates" of piece earnings in the building, engineering, and printing trades, and some municipal employments, while the level of "real wages" is represented by combining the index numbers of rent and prices, and of wages in the building, engineering, and printing trades.

The results of the inquiry, so far as France alone is concerned, are given in the following table :-

\begin{tabular}{|c|c|c|c|c|c|}
\hline \multirow{2}{*}{ Geographical Group. } & \multicolumn{5}{|c|}{ Mean Index Numbers. } \\
\hline & Rent. & $\begin{array}{l}\text { Food } \\
\text { Prices. }\end{array}$ & $\begin{array}{c}\text { Rent and } \\
\text { Prices } \\
\text { Combined. }\end{array}$ & Wages. $^{1}$ & $\begin{array}{l}\text { "Real } \\
\text { Wages." }\end{array}$ \\
\hline $\begin{array}{l}\text { Paris .... } \\
\text { Nord and Pas-de-Calais ........ } \\
\text { Other Northern towns ...... } \\
\text { North-Eastern towns ......... } \\
\text { North-Western towns......... } \\
\text { Central towns ................... } \\
\text { Southern towns }\end{array}$ & $\begin{array}{r}100 \\
52 \\
60 \\
62 \\
56 \\
54 \\
60\end{array}$ & $\begin{array}{r}100 \\
99 \\
100 \\
95 \\
93 \\
94 \\
108\end{array}$ & $\begin{array}{r}100 \\
91 \\
93 \\
90 \\
87 \\
87 \\
100\end{array}$ & $\begin{array}{r}100 \\
67 \\
69 \\
70 \\
64 \\
71 \\
70\end{array}$ & $\begin{array}{r}100 \\
74 \\
74 \\
78 \\
74 \\
82 \\
70\end{array}$ \\
\hline
\end{tabular}

1 Skilled men in building, engineering, and printing trades.

The second part of the general report is occupied with a comparison of the cost of living in England and Wales, France, and Germany. International statistical comparisons of any sort are beset with difficulties. In this case, the difficulties are many, arising, on the one hand, from paucity of data, and on the other from the incommensurability, as it were, of such data as are available. The rent levels of the three countries are given as 100 for England and Wales, 101 for Germany, and 80 for France. But, as already implied above, English rents usually cover local taxation charges, the German cover, under this head, only water charges, while the French rents generally cannot be said to include any direct charges for public purposes. The Board of Trade, after communication with the authorities of a number of towns in England and Wales, estimated that, on the average, 18 per cent. of the Englishman's rent was on account of local taxation (apart from water-rate), and making an allowance to this extent in the index numbers, it was concluded that net rents are relatively 100 in England and Wales, 123 in Germany, and 98 in France. Except that these numbers exhibit the relation of 
rents for corresponding numbers of rooms in the three countries, they can in hardly any sense be held to measure the relative costs of real housing facilities and advantages. In England and Wales the predominant type of working-class dwelling was found to be a small self-contained house of four or five rooms and a scullery. In Germany a two- or, more often, three-roomed flat in a tenement house was found to be the prevailing type. In France, both these types of dwelling prevail, the usual number of rooms being two to three, but frequently, in the case of tenements, only one. As regards the number of rooms occupied, therefore, France appears worse off than Germany, and Germany worse off than England. But with respect to size of rooms this relation is reversed, the typical French rooms measuring from 120 to 200 square feet in area, the German from 100 to 170, and the English from 100 to 150. Further, the water supply and sanitation of the English dwelling are stated to be superior to the French. For most of these differences in housing conditions the rent index numbers make no allowance.

In the international comparison of the cost and consumption of food and fuel, the difficulties are again great. In the first place, the price quotations of only one month, namely, October, 1905, can hardly be accepted as a satisfactory basis, either for comparisons between different countries (still less between different times), or for a statement, where the items are so few, of the average cost of food and fuel to the working man. Then the items entering into the family food bills of the respective countries are not altogether identical. Where the Englishman consumes tea, the Frenchman or German takes coffee. The item meat in the French family comprises 35.5 per cent. beef, 13.5 per cent. veal, 12 per cent. mutton, 11 per cent. horseflesh, 9 per cent. poultry, and 19 per cent. pork, sausage, bacon, \&c. In Germany, the meat consumption is made up of 30 per cent. beef, 27 per cent. sausage, 21 per cent. pórk, 10 per cent. bacon, and 12 per cent. veal, mutton, poultry, \&c. Such a detailed analysis of the English meat diet cannot be given, but beef, mutton, pork, and bacon are estimated to account for 85 per cent. to 90 per cent. of the total. Besides these differences in proportions, there exist also considerable differences in the qualities of the food consumed. Furthermore, it should be noted that the German usually buys his meat free from bone and fat. As regards fuel, it has already been mentioned that many French working-class families burn wood rather than coal. In forming the price index numbers for the separate countries, prices were weighted by the average 
weekly quantities consumed by a working-class family. It was found that the French family was about 25 per cent. smaller than the English, and the German about 12 per cent. smaller. Since these differences are chiefly due to differences in the numbers of very small children in the families, not only the quantities but also the kinds of food consumed would be affected as between one country and another. Such diverse elements as these render extremely difficult, if not altogether impossible, a direct comparison of the cost of food and fuel to the working classes in the different countries. The Board of Trade have, however, dealt with the problem in a practical way, though without solving all the points at issue, by estimating the cost of food and fuel to an English family which may endeavour to maintain, in France or Germany, the same standard of life to which it was accustomed in England. In other words, the Board of Trade have represented the "change in cost to the Englishman if English prices for certain commodities rose to the level of prices in France [or Germany], and the Englishman failed to adjust his budget, e.g., by the purchase of more milk and less meat, to meet the altered conditions." (French report, p. xlii.) The levels of prices so interpreted are given as 100 for England and Wales, 118 for France, and 118 for Germany.

In estimating the levels of wages in the three countries, comparatively few data have been used, and these not homogeneous. Wages in the engineering, building, and printing trades alone were available for comparison. Standard time rates were used in the case of the engineering and printing trades in England and Wales, and similar rates for the printing trades in Germany. But the wages quoted for France, for the building trades in England and Wales, and for the building and engineering trades in Germany were actual earnings. Index numbers constructed from such different kinds of facts are necessarily unsatisfactory, and probably, as the reports suggest, they cause the German and French wage levels to appear slightly more favourable in relation to the English than they really are. The index numbers are 100 for England and Wales, 75 for France, and 83 for Germany. Hours of labour were found to be in the proportion of 100 for England and Wales, 117 for France, and 111 for Germany, whence the hourly wages or earnings are given as 100,64, and 75 respective!y. In forming these index numbers, no account is taken of regularity of employment, so that they afford no safe guide to the relative level of annual earnings, which are more important to the working man than rates of wages or even weekly earnings. 
Speaking generally, then, though with an unknown margin of error, this investigation goes to show that an English workingclass family which should migrate to France and endeavour to maintain there the same mode of life as in its native country, would find rent at not quite the same level as in England, food and fuel about 18 per cent. dearer, wages about 25 per cent. less, and hours of labour about 17 per cent. longer. If the family migrated to Germany, rent would be found to be about 23 per cent. higher than at home, food and fuel probably something less than 18 per cent. dearer, wages about 17 per cent. lower, and hours of labour about 11 per cent. longer.

Incidentally, the investigation has shown that in all three countries rent tends to increase with the size of the town, though between towns of a given size the variations are wide, and that the percentage of total family income spent on food diminishes steadily with the size of the income, although the actual expenditure' on food increases.

In conclusion, a word of congratulation is due to the Board of Trade for the completion of a valuable series of works on the life of the working classes in three of the most important industrial countries of Europe. One should also add a word of sincere regret at the loss of the man who controlled the investigationMr. A. Wilson Fox, C.B.

\section{A. D. WebB}

Report of an Enquiry by the Board of Trade into the Earnings and Hours of Labour of Workpeople of the United Kingdom. I. Textile Trades in 1906. [Cd. 4545.] 1909. Price $2 s .7 d$.

THE Wage Census of 1886 had no successor until 1906, when a general inquiry was organised by the Board of Trade into the "earnings and hours of labour in all trades in the United Kingdom." The final results of this latter inquiry will cover about three times as many workpeople, and will be more detailed and elaborate than those of the earlier census. The two censuses differ, however, in that the 1886 inquiry was undertaken primarily "to obtain the rates of wages for a full time week," while that of 1906 sought to ascertain "the actual earnings of each individual, irrespective of the number of hours worked." In the report under review are presented the results of the recent inquiry so far as they relate to the textile trades.

Schedules were issued to employers asking for information 